\title{
SISTEM KONTROL CATU DAYA, SUHU DAN KELEMBABAN UDARA BERBASIS ATMEGA 2560 PADA RUANG BUNKER SEISMOMETER
}

\author{
Alhusen Mustarang \\ Stasiun Geofisika Palu \\ Badan Meteorologi Klimatologi Dan Geofisika \\ Email: alhusenmustarang007@gmail.com \\ Hapsoro Agung Nugroho \\ Program Studi Instrumentasi-MKG \\ Sekolah Tinggi Meteorologi Klimatologi Dan Geofisika \\ Email: hapsoro.agung@bmkg.go.id
}

\begin{abstract}
ABSTRAK
Bunker merupakan suatu ruang bawah tanah tempat seismometer dioperasikan. Suhu, kelembaban udara serta arus dan tegangan salah satu faktor yang dapat mempengaruhi kinerja seismometer. Monitoring dan kontrol terhadap faktor-faktor tersebut dapat mengurangi resiko kerusakan serta memperpanjang life time dari seismometer. Metodologi penelitian dilakukan dengan melakukan pengukuran terhadap suhu dan kelembaban menggunakan sensor SHT11 dengan kontrol ruang bunker menggunakan kipas DC. Pengukuran arus dan tegangan menggunakan sensor ACS712. Sensor tegangan yang dikontrol berdasarkan waktu pada Real Time Clock. Pengolahan hasil pengukuran menggunakan ATMega 2560 dan ditampilkan pada LCD. Monitoring terhadap keseluruhan sistem menggunakan komunikasi SMS. Pengujian sistem dilakukan dalam ruang bunker seismometer Sekolah Tinggi Meteorologi Klimatologi Dan Geofisika. Hasil penelitian menunjukan bahwa sistem yang dirancang dapat bekerja dengan baik.
\end{abstract}

Kata kunci: bunker seimometer, sensor SHT11, sensor acs712, SMS.

\section{ABSTRACT}

Bunker is a basement room where seismometers operated. Temperature, humidity as well as current and voltage of among the factors that can affect the performance seismometers. Monitoring and control of these factors can reduce the risk of damage and extend the life time of a seismometer. The Method of this research was conducted by measuring the temperature and humidity using SHT11 sensor to the control room using a fan DC bunker. Current and voltage measurements using sensors ACS712. Sensor voltage is controlled based on the Real Time Clock time. Processing of measurement results using ATMega 2560 and displayed on the LCD. Monitoring the whole system using SMS communication. Tests performed in a bunker system seismometers School of Meteorology Climatology and Geophysics. The results of research showed that the designed system can work properly.

Keywords: bunker seismometer, SHT11 sensors, ACS712 sensors, SMS.

\section{PENDAHULUAN}

Seismometer biasanya disimpan di dalam sebuah bunker. Bunker yang dimaksud adalah sebuah ruang bawah tanah tempat seismometer dioperasikan. Lokasi bunker harus aman dan jauh dari aktifitas masyarakat. Lokasi tersebut dimaksudkan untuk mengurangi noise saat pengukuran gempa bumi. Faktor yang dapat mempengaruhi pengukuran seismometer adalah suhu dan kelembaban di dalam ruang bunker. Suhu dan kelembaban yang terdapat di dalam ruang bunker seismometer cenderung lebih tinggi dibandingkan dengan suhu di luar bunker.

Tingginya suhu di dalam ruang bunker disebabkan karena lokasi bunker seismometer berada di bawah tanah. Faktor lain yang mempengaruhi hasil pengukuran seismometer adalah arus dan tegangan yang dihasilkan dari solar cell. Beberapa kejadian yang sering terjadi di stasiun pengamatan gempa bumi, yaitu seismometer yang tersimpan di dalam bunker sering tidak beroperasi maksimal karena tidak adanya arus dan tegangan yang dihasilkan dari solar cell.

Beberapa penelitian terkait monitoring suhu dan kelembaban udara diantaranya adalah Atmoko, 2013 [1] yang melakukan penelitian sistem monitoring serta pengendalian suhu dan kelembaban ruang pada rumah walet menggunakan sensor DHT11 dengan komunikasi web, android dan SMS. Penelitian selanjutnya dilakukan oleh Mandarani, 2014 [2] dengan melakukan perancangan sistem monitoring suhu dan kelembaban menggunakan sensor DHT11 berbasis user interface web. Terkait penelitian monitoring arus dan tegangan Fitriandi, 2016 [3] 
melakukan penelitian rancang bangun alat monitoring arus dan tegangan berbasis mikrokontroler dengan SMS gateway. Pada penelitian ini akan menggabungkan sistem monitoring dan pengendalian suhu dan kelembaban serta arus dan tegangan pada ruangan bunker seismometer dengan menggunakan komunikasi SMS.

SHT11 adalah sebuah single chip sensor suhu dan kelembaban relatif dengan multi modul sensor yang outputnya telah dikalibrasikan secara digital. Pada bagian dalamnya terdapat kapasitif polimer sebagai elemen untuk sensor kelembaban relatif dan sebuah pita regangan yang digunakan sebagai sensor temperatur. Keluaran kedua besaran fisis tersebut digabungkan dan dihubungkan pada Analog to Digital Convereter 14 bit dan sebuah interface serial pada satu chip yang sama. Sensor ini menghasilkan sinyal keluaran yang baik dengan waktu respon yang cepat. SHT11 dikalibrasi pada ruangan dengan kelembaban yang teliti menggunakan hygrometer sebagai referensinya [4].

Sensor Arus ACS712 menggunakan teknologi efek ruang (hall effect) yang diterapkan oleh perusahaan Allegro menggantikan resistor pelangsir dan transformator arus, menjadi sebuah sensor yang mampu mengukur arus. Sensor Efek Ruang (Hall Effect Sensors) adalah suatu transduser yang dapat mengubah besaran medan magnet menjadi besaran listrik yaitu berupa tegangan. Jenis sensor ini dalam pengoperasiannya untuk mendeteksi kedekatan, keberadaan atau ketiadaan medan magnet dari objek [5].

Sensor tegangan merupakan rangkain resistor seri yang sering disebut sebagai rangkaian pembagi tegangan. Rangkaian pembagi tegangan merupakan rangkaian sederhana di mana masukan tegangan sumber dibagi menjadi $1 \mathrm{~V}, 2 \mathrm{~V}$ dan $6 \mathrm{~V}$. Modul ini dapat mengurangi tegangan input hingga 5 kali dari tegangan asli. Tegangan analog input maksimum mikrokontroler yaitu 5 volt, sehingga modul tegangan dapat diberi masukkan tidak melebihi 5 X 5 Volt atau sebesar 25 Volt [6]

\section{METODOLOGI PENELITIAN}

Perancangan sistem seperti pada Gambar 1. terdiri dari Mikrokontroler ATMega2560 sebagai pengumpul dan pengolahan data, sensor SHT11 sebagai sensor pengukur suhu dan kelembaban ruang bunker seismometer, RTC DS3231 sebagai penanda waktu yang presisi, Sensor Arus ACS712 sebagai sensor pengukur arus dari solar cell yang masuk ke baterai, Sensor tegangan untuk membatasi tegangan baterai ke mikrokontroler, relay sebagai saklar antara baterai 1 dan baterai 2, Kipas angin DC sebagai pengontrol suhu ruang bunker, LCD 20x4 sebagai penampil hasil pengolahan dari mikrokontroler, serta modem Wavecom 1306B sebagai pengirim hasil pembacaan perubahan suhu dan tegangan ke user. Secara keseluruhan blok diagram terbagi atas 3 bagian utama yaitu: input (sensor suhu, sensor arus, sensor tegangan dan RTC), proses ( kontrol yang dilakukan oleh mikrokontroler), dan output (LCD, modem Wavecom, kipas angin DC dan Relay) yang saling terhubung sehingga sistem dapat bekerja dengan baik

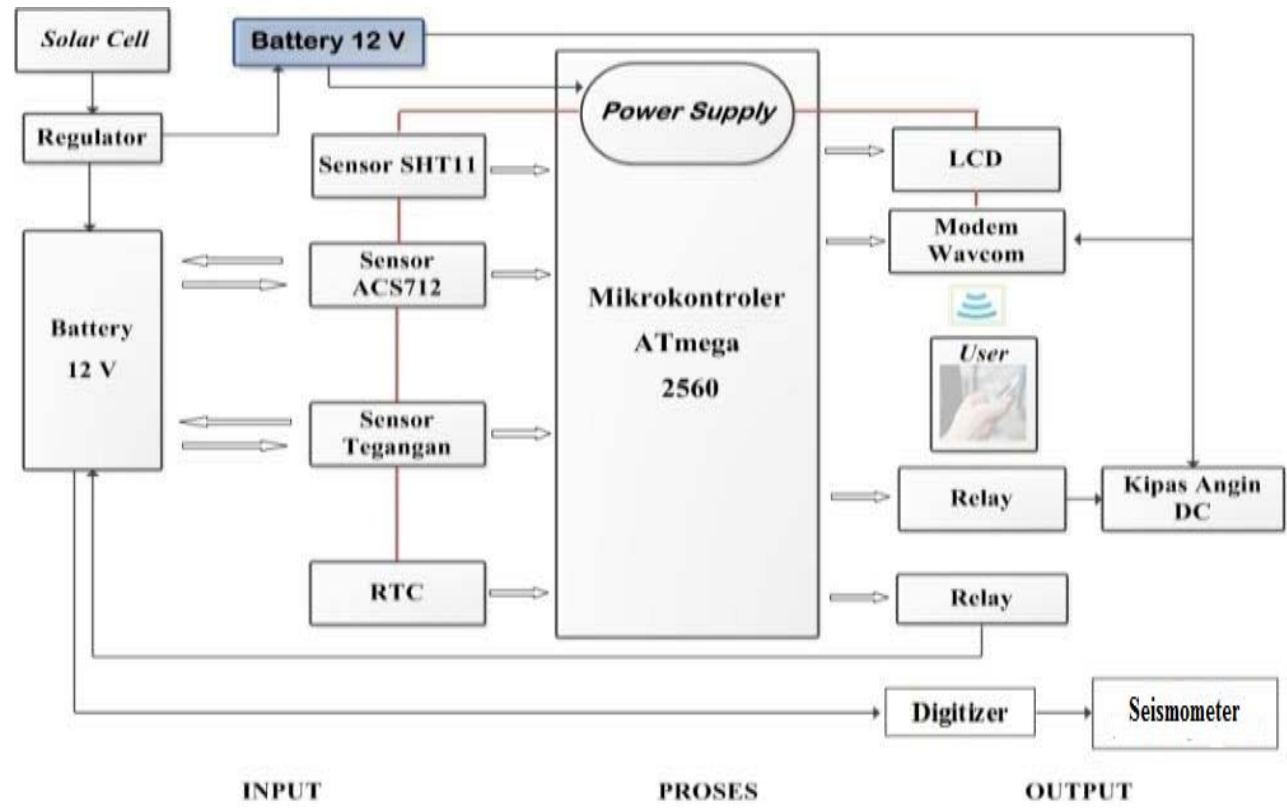

Gambar 1. Diagram Blok Sistem

Diagram alir sistem Gambar 2. diawali dengan proses inisialisasi port-port yang digunakan, kemudian mikrokontroler mulai membaca output sensor dan melakukan akuisisi data. Hasil pembacaan suhu dan kelembaban ruang bunker serta arus dan tegangan yang dihasilkan dari baterai serta waktu pembacaannya akan di tampilkan di 
LCD. Apabila terjadi perubahan baik perubahan suhu maupun perubahan tegangan, maka perubahan tersebut akan di kirim ke user. Perubahan dan hasil pembacaan pada LCD tersebut akan dikirim ke user menggunakan modem Wavecom dengan sistem komunikasi SMS.

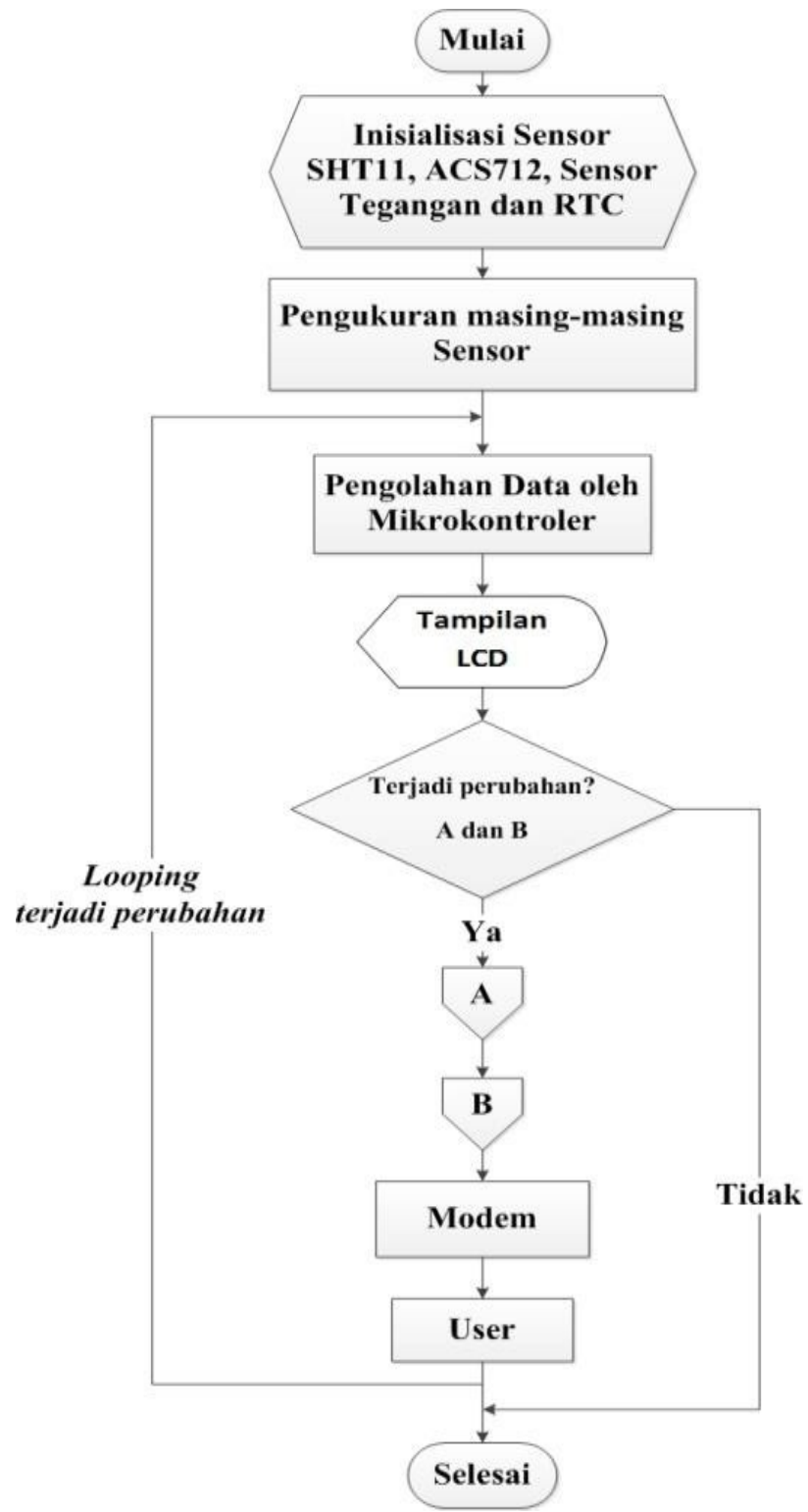

Gambar 2. Diagram Alir Sistem 

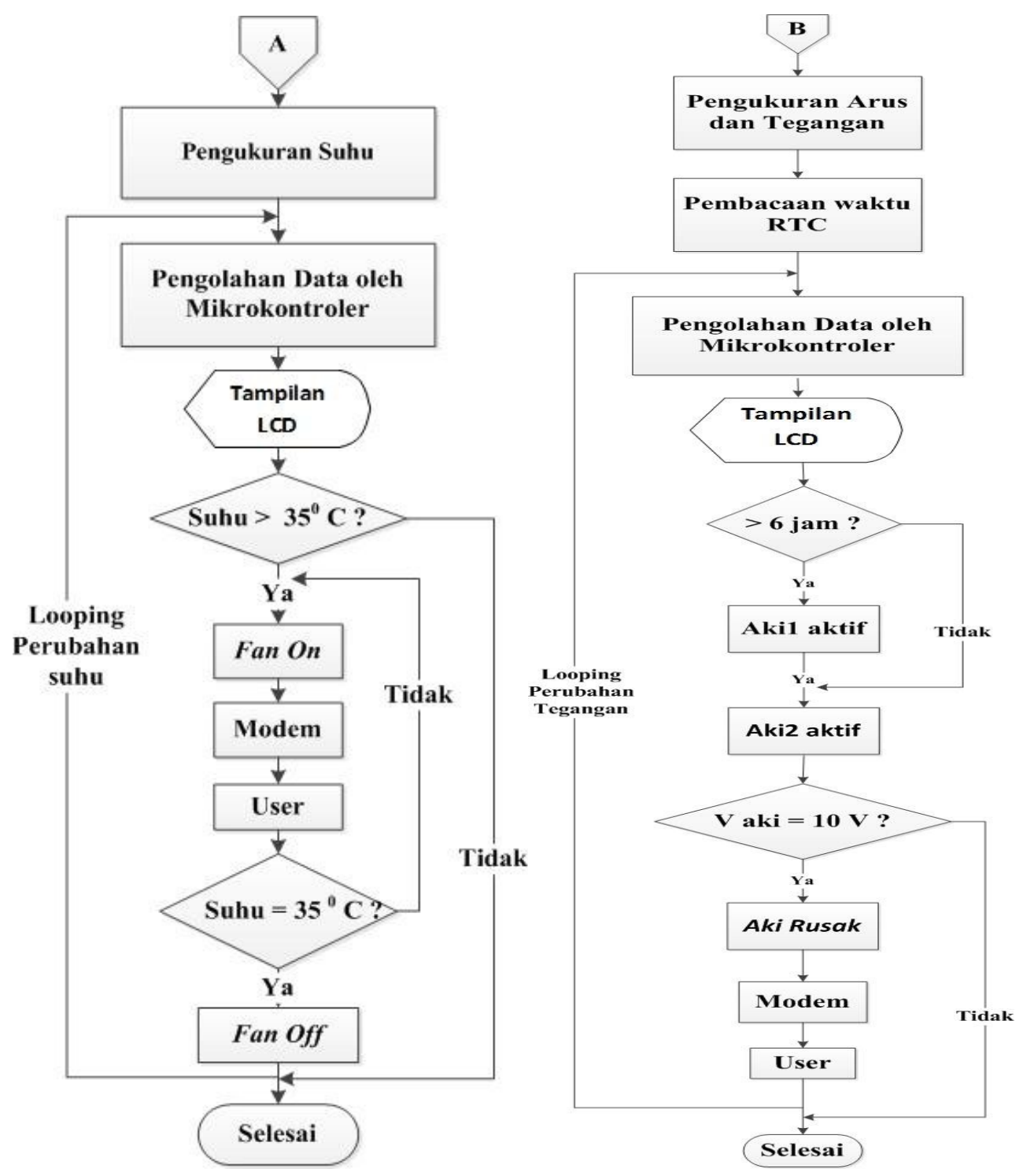

Gambar 3. Diagram Alir Perubahan Suhu dan Tegangan

Pada Gambar 3. menunjukan proses saat terjadinya perubahan suhu dan tegangan. Suhu maksimal yang diukur dari sistem yaitu suhu $35^{\circ} \mathrm{C}$. Saat suhu di dalam ruang bunker melewati batas maksimal , maka kipas akan berputar. Saat kipas berputar udara panas akan dibuang keluar melalui pipa pembuangan udara, sehingga suhu ruang bunker kembali normal. Kipas (fan) akan berhenti berputar jika suhu di dalam ruang bunker kurang dari $35^{\circ} \mathrm{C}$.

Sistem ini juga akan mengontrol tegangan yang dihasilkan dari solar cell yang masuk ke baterai berdasarkan waktu. baterai 1 akan digunakan dari jam (06.00-12.00 WIB) dan baterai 2 akan digunakan pada jam (12.00-18.00 WIB). Setelah jam 18.00 WIB, maka beban akan dialihkan kembali ke baterai 1 dari (18.00-00.00 WIB), kemudian setelah jam (00.00 WIB) beban akan dialihkan lagi ke baterai 2 (00.00-08.00 WIB). Dua buah baterai ini akan digunakan selama 24 jam secara bergantian secara otomatis berdasarkan pembagian waktu.

LCD menampilkan tegangan dari salah satu baterai kurang dari $10 \mathrm{~V}$, maka secara otomatis hasil pengukuran tersebut akan dikirim ke user melalui pesan singkat SMS dengan menggunakan modem Wavecom sebagai peringatan bahwa baterai tersebut sudah tidak dapat digunakan dan harus segara diganti. LCD akan menampilkan hasil pembacaan dari masing-masing sensor berupa suhu, kelembaban arus dan tegangan serta waktu pembaacaan sensor.

Input ke sistem dan modem menggunakan input-an tersendiri tanpa mengganggu input-an ke seismometer. Hal ini dilakukan agar kontrol alat ke baterai lebih maksimal sehingga tidak megganggu hasil pembacaan dari seismometer. 


\subsection{Perancangan Perangkat Keras}

Dalam konsep rancangan ini, akan dibuat sebuah konsep perancangan perangkat keras yang dapat mengukur suhu dan kelembaban serta arus dan tegangan baterai. Konsep rancangan perangkat keras dibuat untuk mempermudah dalam penempatan dari sistem. Konsep perancangan perangkat keras seperti ditunjukan pada Gambar 4.

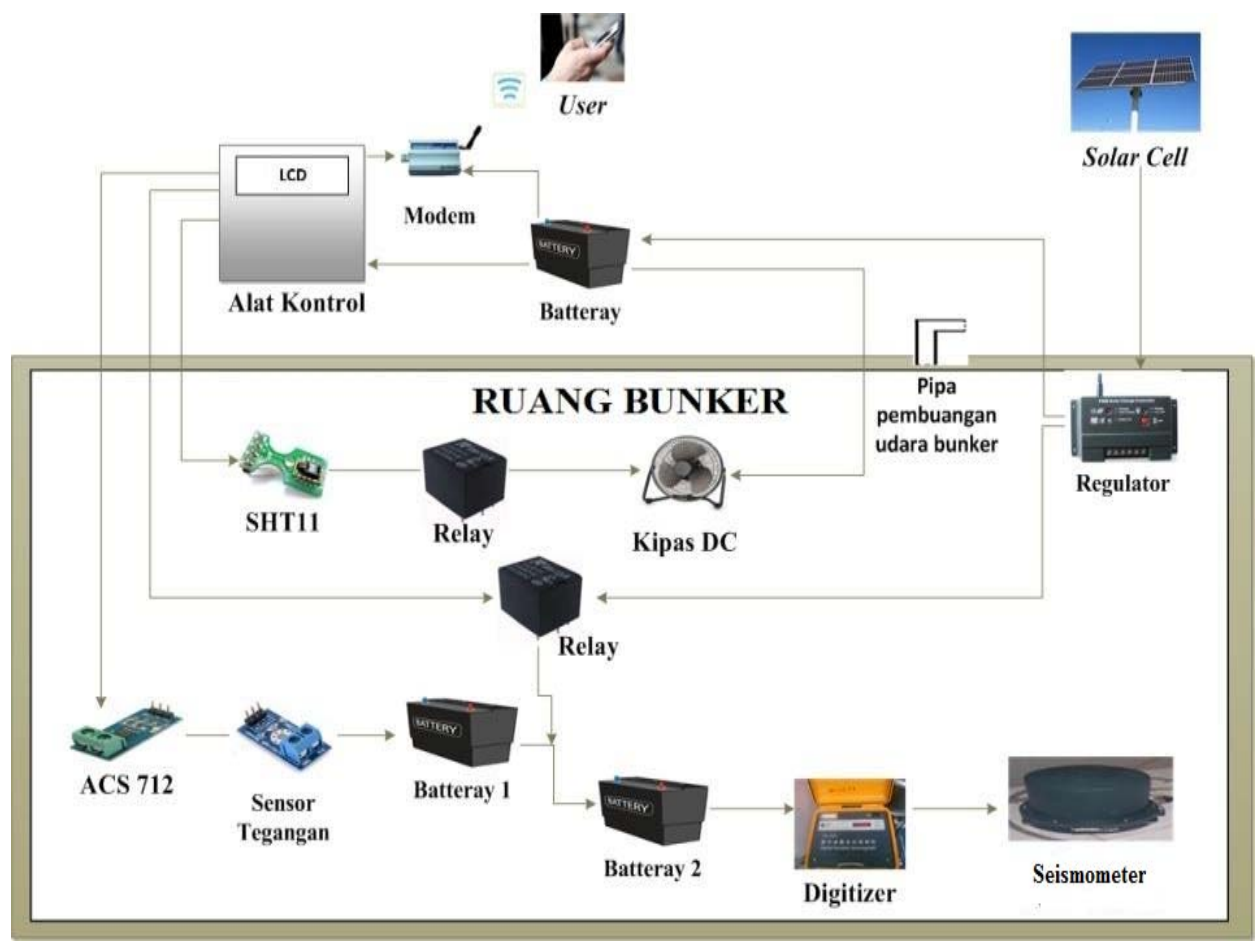

Gambar 4. Konsep Perancangan Perangkat Keras

\subsection{Perancangan Hasil Pembacaan Sistem}

Konsep perancangan hasil pembacaan sistem yang telah dibuat merupakan konsep perancangan ketika terjadi perubahan suhu maupun tegangan. Konsepnya menggunakan pesan singkat SMS, dimana pesan tersebut akan digunakan untuk menampilkan keluaran data suhu dan kelembaban ruang bunker, arus dan tegangan yang dihasilkan solar cell serta waktu terjadinya perubahan. Konsep perancangan hasil pembacaan alat pada saat terjadi perubahan dapat dilihat pada Gambar 5.

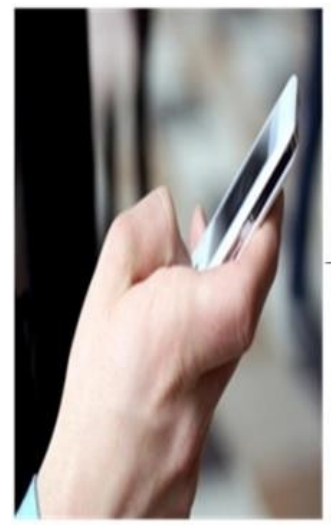

User

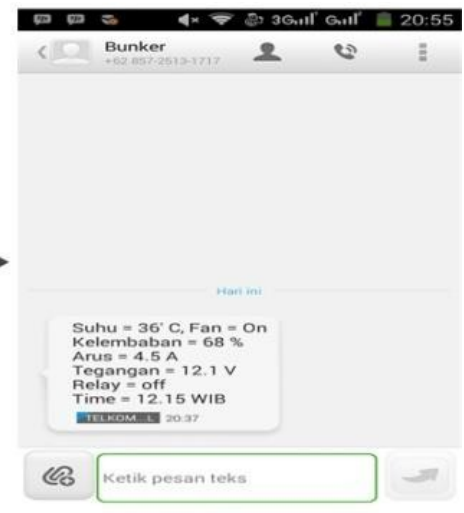

Gambar 5. Konsep Perancangan Hasil Pembacaan Sistem 


\section{HASIL DAN PEMBAHASAN}

Sistem yang telah dibuat ini akan di tempatkan di dalam sebuah bunker yang di dalamnya terdapat regulator, power supply dari solar cell, baterai, digitizer dan seismometer. Sistem ini akan mengontrol suhu dan kelembaban ruang bunker serta arus dan tegangan dari solar cell yang masuk kedalam baterai. Gambar 6. merupakan sistem yang telah dibangun.

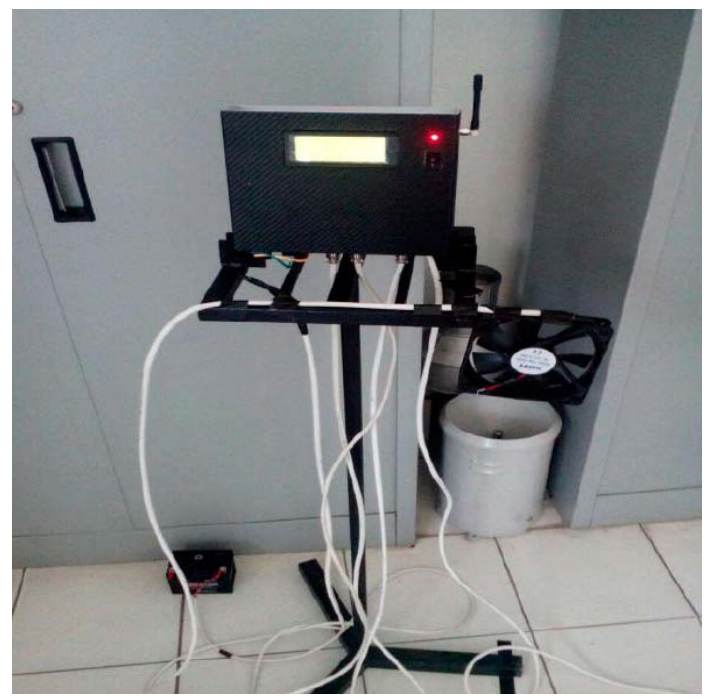

\section{Gambar 6. Konsep Perancangan Hasil Pembacaan Sistem}

Pengujian dari sistem yaitu dengan uji lapang terhadap sistem. Uji lapang dilakukan untuk menguji apakah sistem telah bekerja dengan baik atau tidak. Saat melakukan pengujian terhadap sistem pada ruang bunker STMKG, sensor SHT11, kipas DC dan baterai diletakan di dalam bunker tempat seismometer terpasang. Display dari sistem kontrol tersebut diletakan di luar tempat seismometer terpasang, sehingga mempermudah dalam pembacaan dari sensor dan tidak mengganggu pembacaan dari seismometer.

\subsection{Uji Lapangan Sensor SHT11}

Sistem yang telah aktif membaca suhu di dalam ruang bunker $26{ }^{\circ} \mathrm{C}$. Suhu yang terbaca sistem merupakan suhu aman dari sistem. Suhu di dalam ruang tersebut disebabkan karena lokasi ruang bunker berada di dalam Laboratorium Meteorologi, yang dimana di dalam ruangan tersebut terpasang alat pendingin ruangan. Gambar 7. menunjukan hasil pengukuran sensor SHT11.

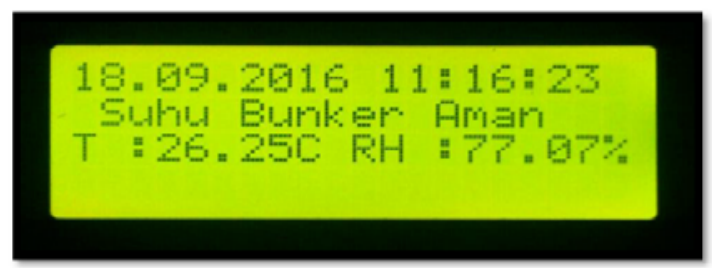

Gambar 7. Hasil Pembacaan Sensor SHT11

Ruangan bunker STMKG menunjukan suhu ruangan aman maka suhu maksimum pada sistem yang sebelumnya $35{ }^{\circ} \mathrm{C}$ diturunkan menjadi $28{ }^{\circ} \mathrm{C}$ untuk menguji sitem tersebut dapat berjalan dengan baik atau tidak. Setelah suhu maksimum dari sistem diturunkan menjadi $28{ }^{\circ} \mathrm{C}$, sistem kemudian membaca adanya perubahan suhu di dalam ruang bunker. Saat sistem membaca suhu melebihi suhu maksimal, perubahan suhu tersebut kemudian langsung dikirimkan ke user sebagai pemberitahuan bahwa suhu di dalam ruang bunker melebihi batas maksimal yaitu $28{ }^{\circ} \mathrm{C}$, seperti terlihat pada Gambar 8 . 


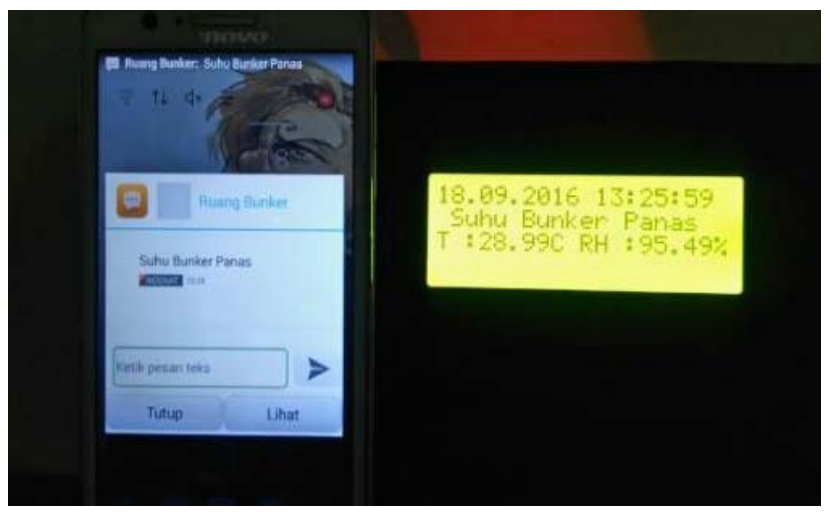

Gambar 8. Perubahan Suhu di Dalam Ruang Bunker

\subsection{Uji Lapangan Sensor Arus dan Tegangan}

Pada uji lapangan sensor arus dan tegangan salah satu dari dua buah baterai yang digunakan tersebut menggunakan baterai kurang dari $12 \mathrm{~V}$. Penggunaan baterai kurang dari $12 \mathrm{~V}$ ini dimaksudkan untuk menguji apakah warning dari sistem berjalan dengan baik atau tidak. Pengujian pembacaan sensor arus dan tegangan ditunjukan Gambar 9.

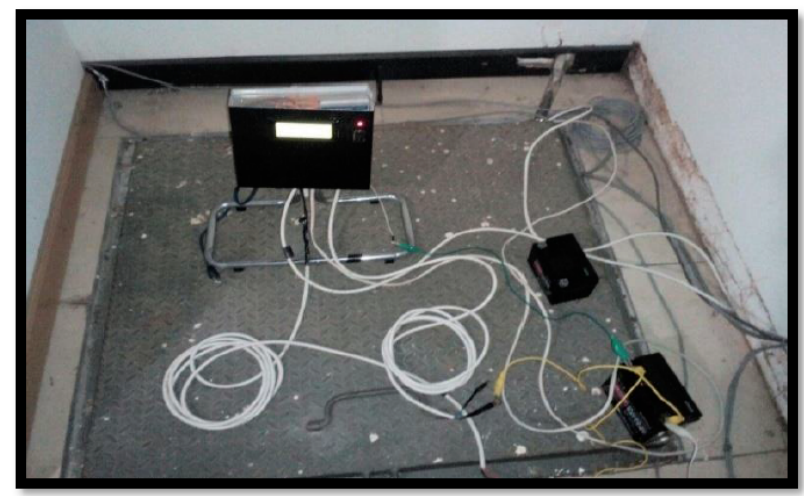

Gambar 9. Hasil Pembacaan Sensor Arus dan Tegangan pada Ruang Bunker

Hasil uji lapangan pada sensor arus dan tegangan Gambar 10. terlihat bahwa arus dan tegangan melakukan pembacaan dengan baik. Saat pengujian sistem pada ruang bunker, baterai yang aktif adalah baterai 1 dengan keterangan bahwa kondisi baterai 1 lebih dari $10 \mathrm{~V}$.

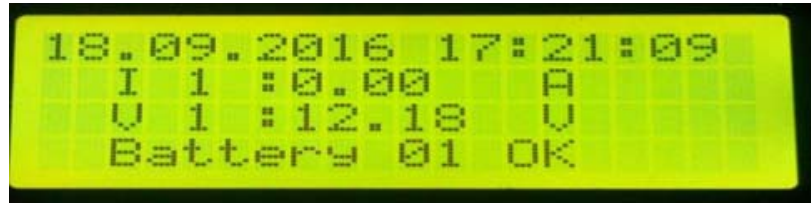

Gambar 10. Tampilan Hasil Pengukuran Sensor Arus dan Tegangan

\subsection{Uji Komunikasi SMS}

Pergantian penggunaan baterai (baterai 1 berpindah ke baterai 2) sistem membaca bahwa baterai 2 dinyatakan error, karena tegangan baterai 2 kurang dari $10 \mathrm{~V}$. Saat baterai 2 dinyatakan error keterangan tersebut langsung dikirmkan ke user sebagai peringatan bahwa baterai tersebut harus diganti, seperti yang ditujukan pada Gambar 11. 


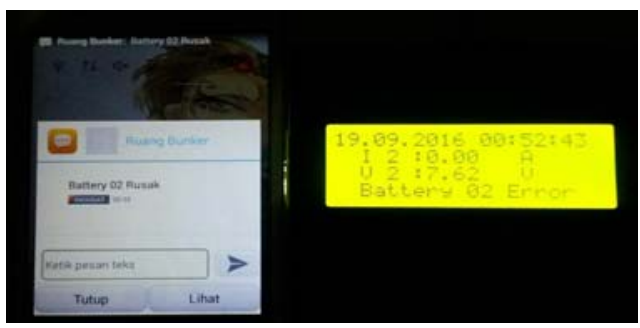

Gambar 11. Tampilan Pesan SMS Saat Terjadi Perubahan Tegangan

Pesan SMS keterangan perubahan tegangan akan terus dikirimkan sampai baterai tersebut diganti seperti yang ditunjukan pada Gambar 12.

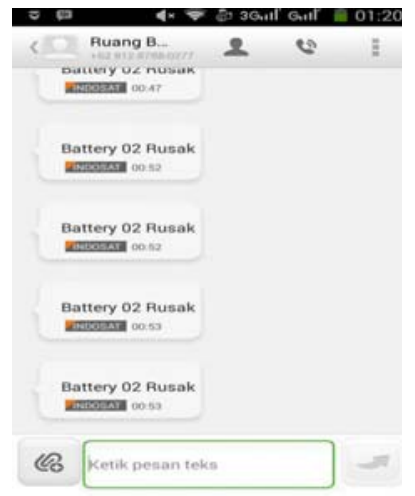

\section{Gambar 12. Tampilan Pesan SMS Saat Terjadi Kerusakan}

\section{KESIMPULAN}

Berdasarkan penelitian yang telah dilakukan, dapat disimpulkan sebagai berikut :

a) Sensor bekerja dengan baik dalam memonitoring perubahan suhu dan tegangan.

b) Pengontrolan pada suhu berjalan dengan baik. Saat sistem membaca suhu lebih dari $28^{\circ} \mathrm{C}$ kipas berputar dan saat suhu kurang dari $28^{\circ} \mathrm{C}$ kipas berhenti.

c) Saat baterai kurang dari $10 \mathrm{~V}$ terjadi perubahan tegangan. Informasi dikirimkan ke user sebagai peringatan.

d) Hasil pengukuran saat terjadi perubahan suhu dan tegangan yang terbaca oleh sensor berhasil dikirim ke user berupa SMS yang berisikan informasi pemberitahuan kondisi di dalam bunker

\section{DAFTAR PUSTAKA}

[1] Atmoko, Rachmad Andri. 2013. "Sistem Monitoring dan Pengendalian Suhu dan Kelembaban Ruang pada Rumah Walet Berbasis Android, Web, dan SMS.” Prosiding Seminar Nasional Teknologi Informasi \& Komunikasi Terapan 2013, 283-290.

[2] Mandarani, Putri. 2014. "Perancangan Dan Implementasi User Interface Berbasis Web Untuk Monitoring Suhu, Kelembaban Dan Asap Pada Ruangan Berbeda Dengan Memanfaatkan Jaringan Local Area Network". Jurnal TEKNOIF, 3. 2, 37-42.

[3] Fitriandi, Afrizal. dkk., 2016. "Rancang Bangun Alat Monitoring Arus dan Tegangan Berbasis Mikrokontroler dengan SMS”. Jurnal Rekayasa dan Teknologi Elektro, 10. 2, 87-98.

[4] Al. 2017. "Perencanaan Wireless Sensor Network (WSN) pada Sistem Monitoring Suhu dan Kelembaban Kamar Jenazah Rumah Sakit M. Djamil”. Jurnal Teknik Elektro ITP, 6. 1, 9-19.

[5] Melipurbowo, B. G. 2016. "Pengukuran Daya Listrik Real Time Dengan Menggunakan Sensor Arus ACS.712”. ORBITH, 12. 1, 17-23.

[6] Fachri, Muhammad Rizal. dkk. 2015. "Pemantauan Parameter Panel Surya Berbasis Arduino secara Real Time". Jurnal Rekayasa Elektrika, 11. 4, 123-128 